\title{
Influence of Soil and Vegetation in the Pollen Spectrum Modeling from Caçapava do Sul, Rio Grande do Sul, Brazil
}

\author{
Evaldt ACP1*, Bauermann SG1 ${ }^{1}$, Paz FR ${ }^{1}$, Lima GL² and Radaeski JN1 \\ 1 Universidade Luterana do Brasil, Laboratório de Palinologia, Av. Farroupilha, Brazil \\ 2Universidade Federal da Fronteira Sul, Avenida Fernando Machado, BraZil
}

Research Article

Volume 3 Issue 3

Received Date: April 27, 2018

Published Date: May 16, 2018

*Corresponding author: Evaldt ACP, Laboratório de Palinologia da Universidade Luterana do Brasil-ULBRA, Universidade Luterana do Brazil, Canoas, Brazil, Email: andreia.biologia@gmail.com

\section{Abstract}

Pollen analysis of surface sediments is an important tool for Quaternary Palynology, by comparing modern and fossil pollen allows to identify analogs processes occurred in the past. Aiming to expand the knowledge about the deposition and preservation of palynomorphs in Rio Grande do Sul, were identified and characterized sets pollen deposited on the soil surface from samples collected in two different vegetation formations (Araucaria forest and grassland) of the Caçapava do Sul. The nine samples were treated with the usual techniques for palynology, granulometry analysis and analysis of organic carbon. The palynological slides are deposited in the reference pollen collection of the Laboratory of Palynology of ULBRA. 300 pollen grains for each sample were quantified and identified. The results obtained with the pollen analysis showed that all pollen reflected the main species of the grassland formation (Poaceae, Asteraceae, Amaranthaceae, Eryngium L. and Vernonia Schreb.), and the Araucaria forest, which highlighted species are Arecaceae, Myrtaceae, Araucaria angustifolia (Bertol.) Kuntze, Podocarpus lambertii Klotzsch ex Endl. and Ilex L.. The results of the physicochemical analysis compared with the results palynological, demonstrated a positive correlation between clay, organic carbon content and the concentration of pollen.

Keywords: Surface Sediments; Pollen Analysis; Pollen-Vegetation Relationships; Granulometry; Organic Carbon Content

\section{Introduction}

Pollen grains are dispersed in the atmosphere and record the changes that occurred in the vegetation communities that are distributed in certain regions over geological time when deposited in environments that favor their deposition [1]. However, the pollen spectrum does not directly reflect the abundance of the vegetation, because many factors interfere in the record, such as the production of pollen grains, dispersion and differential preservation of the taxa [2-6]. All interpretations of pollen assemblages (quantitative or qualitative) are based on explicit or implicit assumptions about how the vegetation composition or other aspects of vegetation are recorded by the pollen spectrum [6,7]. In this sense, pollen analysis of surface sediments shows to be an important tool to Quaternary Palynology, because allows identify analogous process occurred in the past. 


\section{Open Access Journal of Agricultural Research}

The advantages of analysis of the surface samples in relation to Quaternary samples are the more pollen preservation and not decrease of the abundance of species, well as well deterioration [5]. However, due to difficulties of interpretation of data in these studies are few the published works in Brazil with data about the comparison between modern pollen spectrum and vegetation [8-10].

In order to increase knowledge about the deposition and preservation of the palynomorphs in Rio Grande do Sul, pollen assemblages deposited on the soil surface were identified and characterized in samples collected in two different vegetation formations (Araucaria forest and grassland) in the Caçapava do Sul region, Rio Grande do Sul, Brazil. In the same time of pollen analysis were made physicochemical analysis to a precise characterization of samples collected.

\section{Materials and Methods}

\section{Study area Features}

\section{Location}

The Caçapava do Sul occur in the "Serra do Sudeste" with the latitude of $30^{\circ} 20^{\prime} \mathrm{S}$ and longitude of $53^{\circ} 18^{\prime} \mathrm{W}$ (Figure 1). The relief of this region is undulate to hilly with sharp slopes and located in the Pampa biome. The elevation is between 100 and 400 meters in most of the area [11]. According to Moreno (1961) this region is characterized by temperate subtropical climate $(\mathrm{Cfb})$ with an annual average temperature of $18^{\circ}$ to $20^{\circ} \mathrm{C}$ [12]. The Serra do Sudeste is also called of Escudo SulRiograndense or Escudo Cristalino due to geological composition main is granite, despite also gnaisse and conglomeratic sandstone occur in the region [13]. The geological diversity is shown in the different soils distributed in the region.

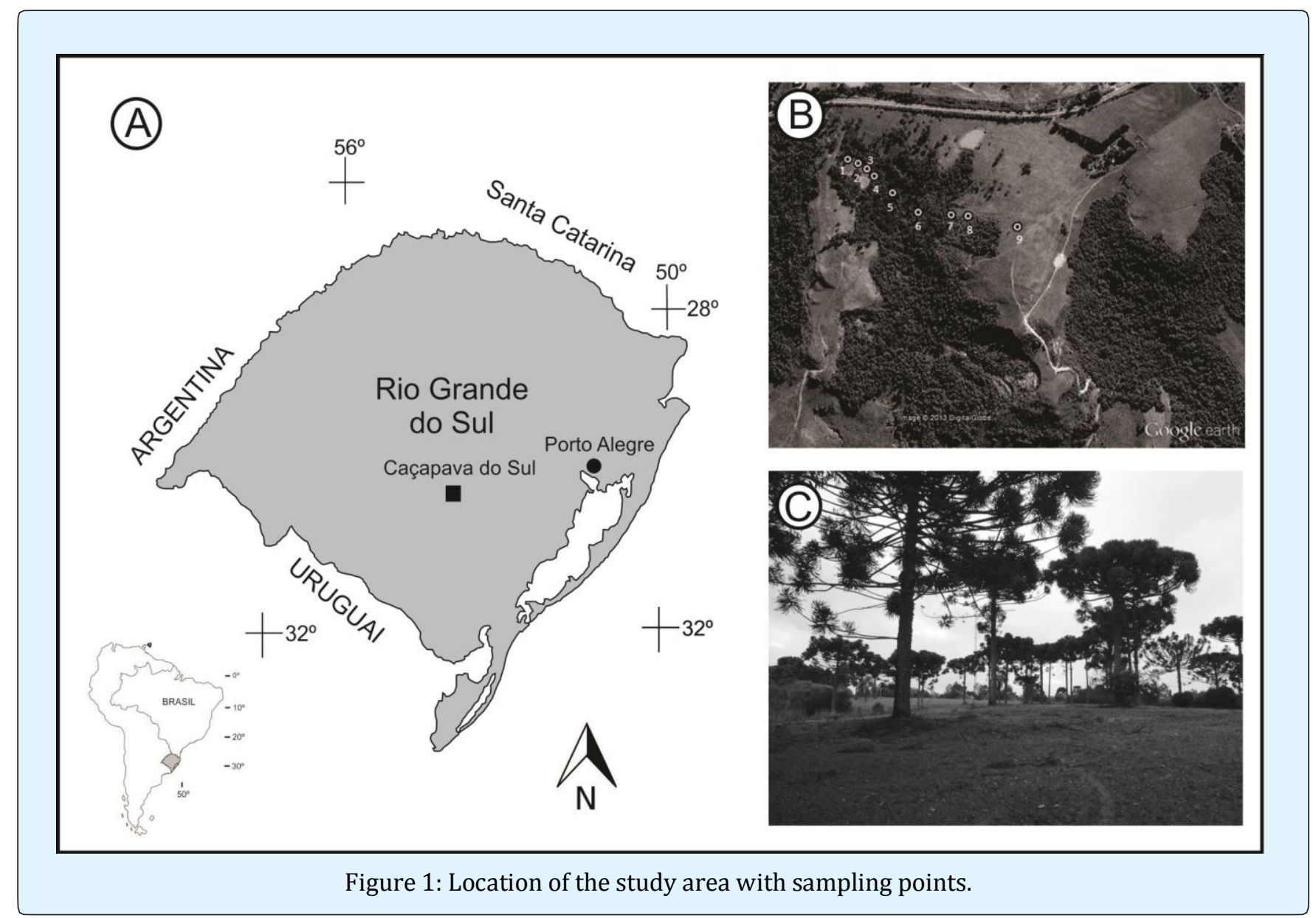




\section{Open Access Journal of Agricultural Research}

\section{Vegetation}

The vegetation of Caçapava do Sul region is characterized by transitional physiognomies vegetation. This region shows a mosaic of herbaceous-shrub and forest formations [14]. Furthermore, this area is the south limit of Araucaria forest [15]. According to Abraão (1992), Caçapava do Sul was a municipally of the high number of forest species and native taxa that predominated, such as "cedro" (Cedrela fissilis Vell.), "louro" (Cordia trichotoma (Vell.) Arrab. ex Steud.), "açoita-cavalo" (Luehea divaricata Mart.), "aroeira" (Lithraea molleoides (Vell.) Engl.), "pitangueira" (Eugenia uniflora L.), and others [16].

The previous identification of plant species in the region recorded 89 taxa belonging to 41 families of grasslands and Araucaria forest. Families with several species in this region are Poaceae (10 species), Asteraceae (10 species), Fabaceae (6 species), Rubiaceae (5 species) and, with less representation, species of Myrtaceae and Sapindaceae [17].

Nine surface samples were collected in different formations of vegetation from Caçapava do Sul $\left(30^{\circ} 20^{\prime} \mathrm{S}\right.$ and 531' $\mathrm{W}$ ). The samples 1 and 2 were collected in grasslands with few species of Araucaria angustifolia, samples 3, 4, 7 and 8 in the grassland/Araucaria forest transition, sample 5 in the Araucaria forest, sample 6 in the open area of Araucaria forest and sample 9 in the grassland without species of Araucaria angustifolia. In each sample were extracted subsamples of $1 \mathrm{~cm}^{3}$ for palynological analysis through of chemical process according to Faegri and Iversen (1989), using $\mathrm{HCl}, \mathrm{HF}$, $\mathrm{KOH}$ and acetolysis [18]. In order to calculate pollen concentration were added two tablets of spore marker, according to propose of Stockmarr (1971) [19].

Four slides were created using glycerinated jelly and the slides are deposited in the collection reference of Laboratório de Palinologia da ULBRA (numbers records of: P-1302, P-1303, P-1305, P-1309, P-1311, P-1314, P1317, P-1318, P-1320). In each sample, 300 pollen grains were identified and quantified using a magnification of 400x of the Leica DMLB microscope. The pollen reference of Laboratório de palinologia da ULBRA and pollen atlas [10,20-27] were consulted to identification of the palynomorphs. The relative frequencies and concentration calculate of palynomorphs, well as well cluster analyzes were carried out in the PSimpoll software [28].

The granulometric and organic carbon content analysis of the nine samples studied were made in the Laboratório de Solos da ULBRA according to methodological propose of Suguio (1973) [29]. The data were plotted in the Textural Diagram adopted by Sociedade Brasileira de Ciência do Solo to show the results and determine the textural classes.

The organic carbon content was determined from an indirect method of organic carbon oxidation by the wet way, proposed by Walkley-Black and the data obtained were grouped according to the quantitative classification for organic carbon and organic matter adopted in the states of Rio Grande do Sul and Santa Catarina [30].

\section{Results}

\section{Palynology}

In the surface samples were identified 38 pollen types, which are 20 species of grasslands, 15 species of Araucaria forest, 2 are non-native species and 1 aquatic taxa.

The surface samples showed significant differences in the composition of the pollen spectrum. In the text are shown only species of percentage $\geq 1 \%$, but all species are shown in the pollen diagrams (Figures 2, 3 and 4). The cluster analysis identified five different sets of samples, which are shown below. 


\section{Open Access Journal of Agricultural Research}

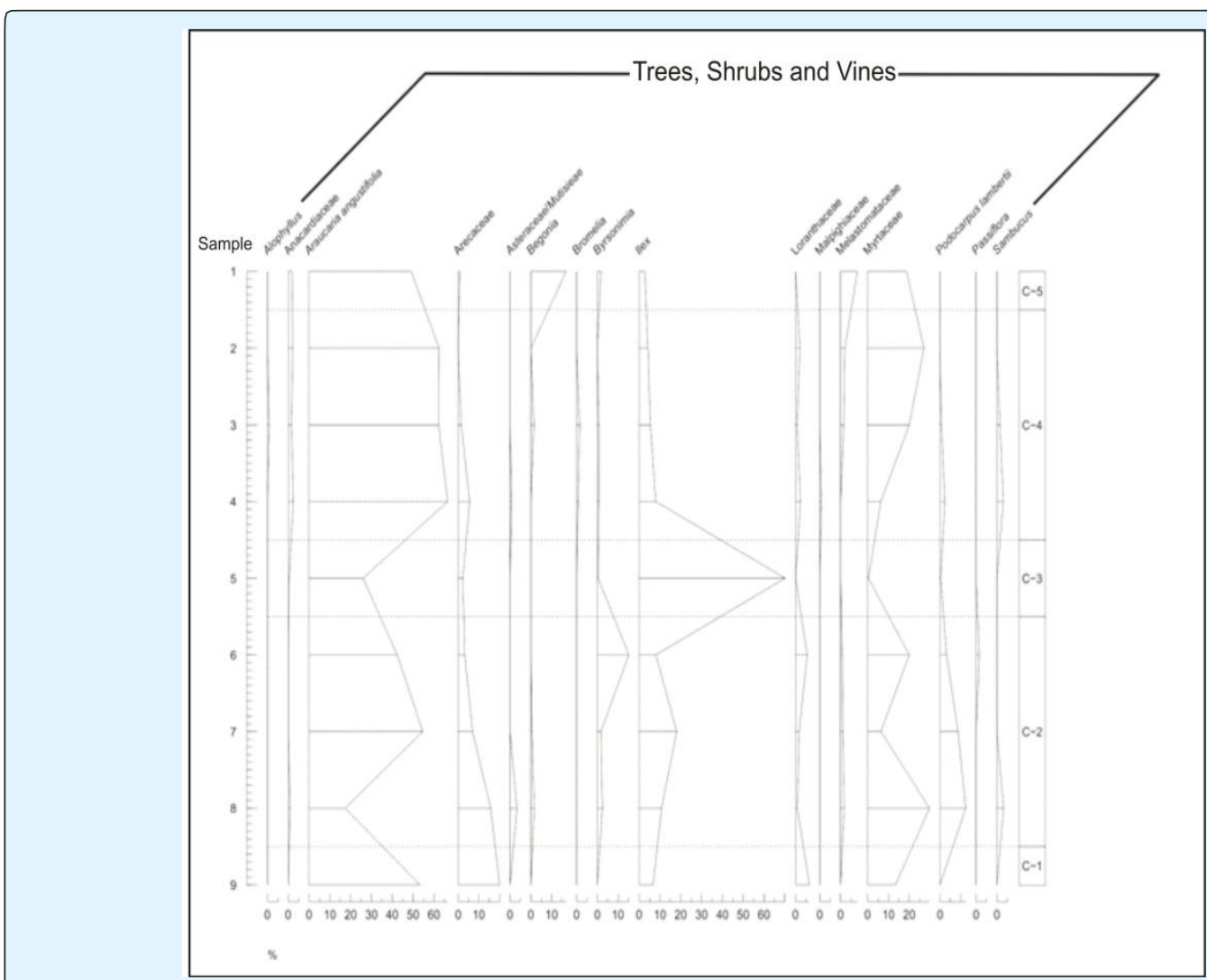

Figure 2: Pollen diagram of the percentage of the sediments profile samples: Trees, Shrubs and Vines.

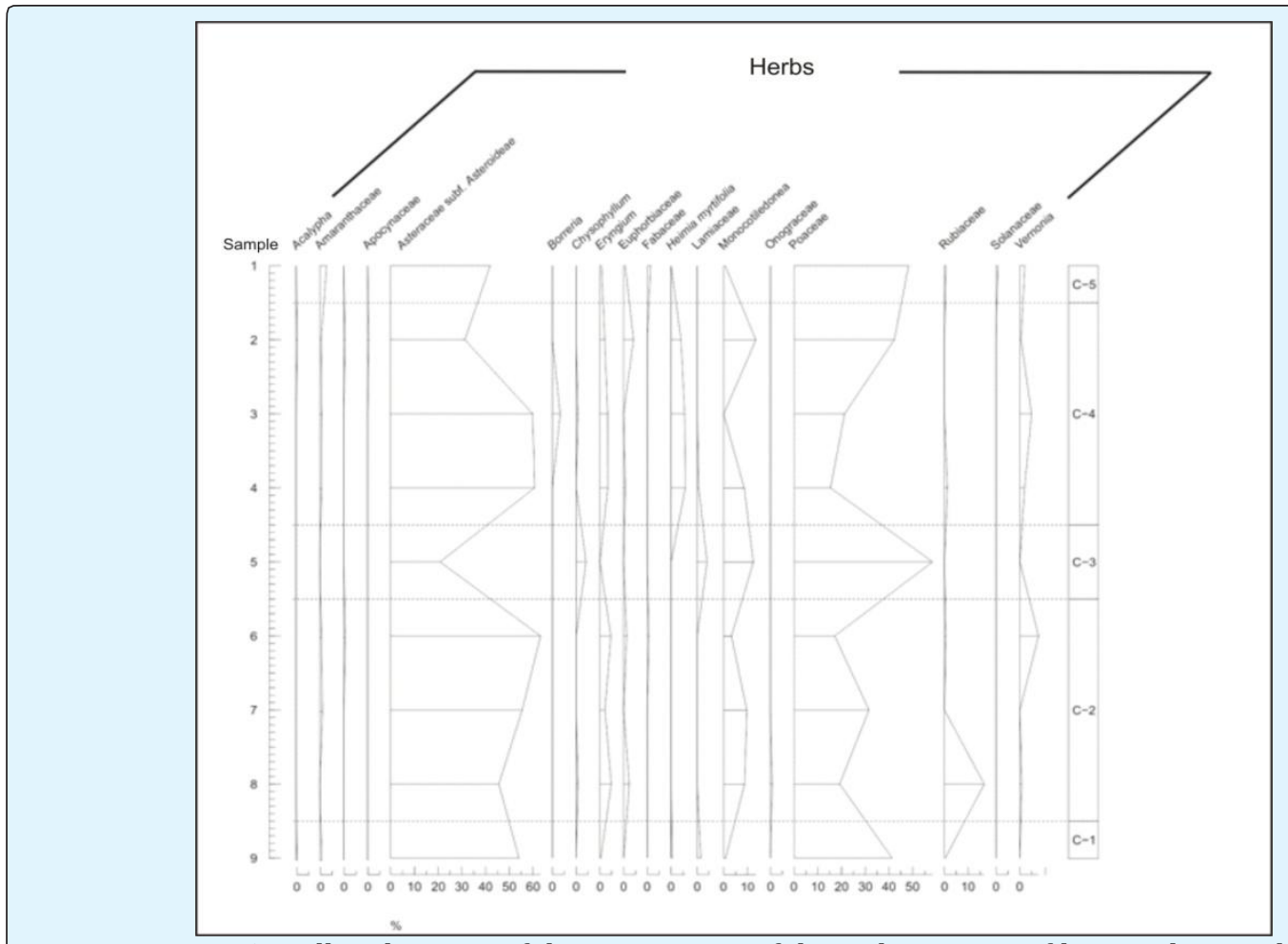

Figure 3: Pollen diagram of the percentage of the sediments profile samples: Herbs. 


\section{Open Access Journal of Agricultural Research}

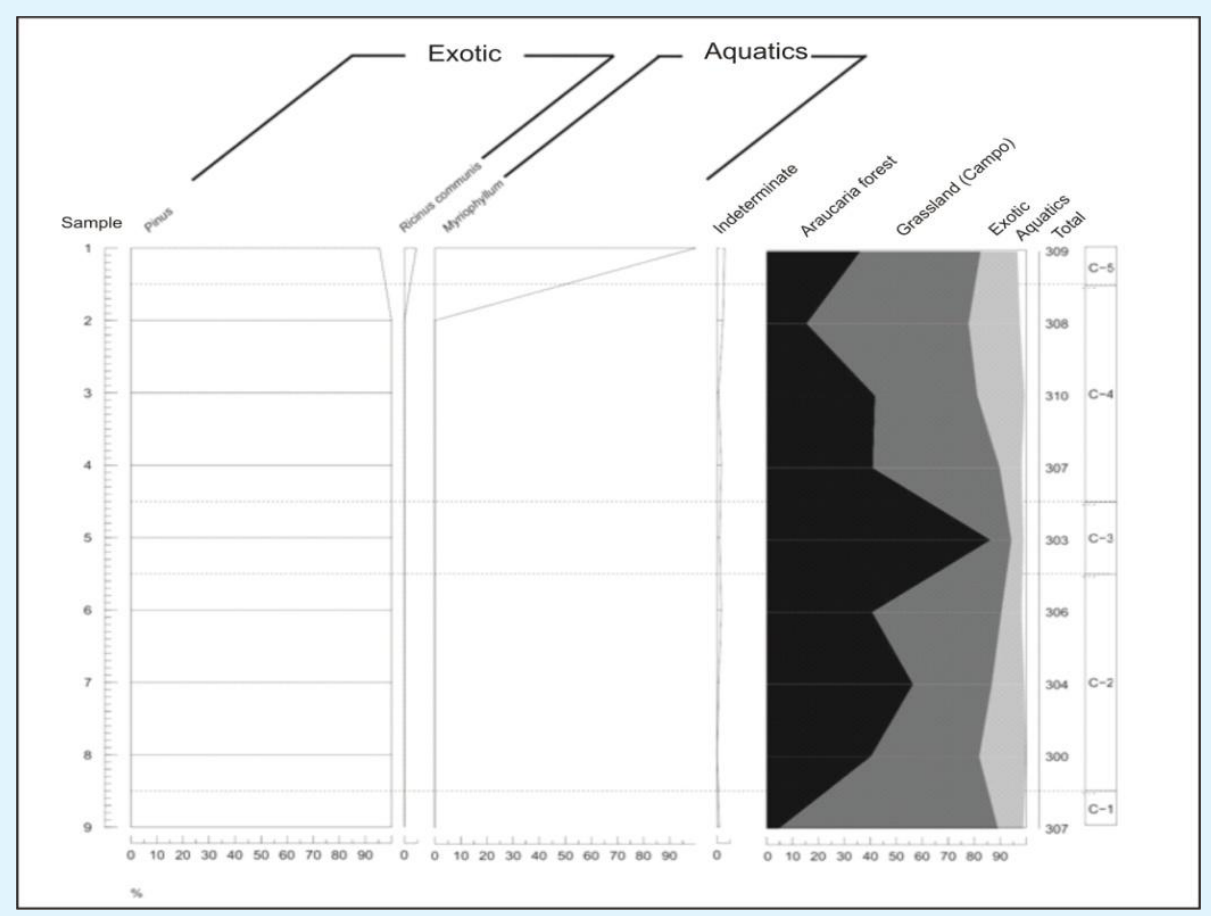

Figure 4: Pollen diagram of the percentage of the sediments profile samples: Exotics, Aquatics and Sums.

The C-1 set is belonging to sample 9 and show a predominance of species of the grasslands, which species of Asteraceae subf. Asteroideae (46\%) and Poaceae (35\%), Pinus L. (10\%) and Araucaria angustifolia (3\%) are the most common taxa.

The C-2 group include the samples 6, 7 and 8 . The vegetation is characterized by species of transitional vegetation of grasslands and Araucaria forest. Sample 6 shows a predominance of Asteraceae subf. Asteroideae (32\%), Araucaria angustifolia (18\%), Poaceae (9\%), Myrtaceae (8\%), Pinus (8\%), Byrsonimia Rich. ex Kunth (6\%), Vernonia (4\%) and Ilex (3\%). Sample 7 recorded the occurrence of Araucaria angustifolia (31\%), Asteraceae subf. Asteroideae (17\%), Pinus (13\%), Ilex (10 $\%$ ), Poaceae (10\%), Podocarpus lambertii (5\%), Arecaceae (4\%), Myrtaceae (4\%) and monocots (3\%). Sample 8 had frequency of Asteraceae subf. Asteroideae (19\%), Pinus (18\%), Myrtaceae (12\%), Poaceae (8\%), Araucaria angustifolia (7\%), Rubiaceae (7\%), Arecaceae (6\%), Podocarpus lambertii (5\%), Ilex (4\%), monocots (4\%) and Eryngium (2\%).

The $\mathrm{C}-3$ set includes the sample 5 that is characterized by almost exclusive species of Araucaria forest and main representative are Ilex (61\%) and Araucaria angustifolia (23\%).
The C- 4 set is characterized by samples 2,3 and 4, and shows species of the transitional vegetation of grasslands and Arauracia forest. The sample 2 shown percentages of Poaceae (27\%), Pinus (20\%), Asteraceae subf. Asteroideae (20\%) and Araucaria angustifolia (10\%), well as well monocots (9\%), Myrtaceae (4\%), Heimia myrtifolia Cham. \& Schltdl. (3\%) and Euphorbiaceae (3\%). Sample 3 is characterized by species of Araucaria angustifolia (26\%), Asteraceae subf. Asteroideae (24\%), Pinus (18\%), well as well Myrtaceae (8\%) and Poaceae (8\%). Sample 4 shown frequencies of the species of Asteraceae subf. Asteroideae (30\%) and Araucaria angustifolia (28\%), well as well (9\%), Poaceae (\%), monocots (4\%), Ilex (3\%), Heimia myrtifolia (3\%) and Myrtaceae (3\%).

The C-5 set includes only the sample 1 and is characterized by species of Poaceae (23\%) Asteraceae subf. Asteroideae (20\%), Araucaria angustifolia (18\%), Pinus (14\%), Myrtaceae (7\%), Begonia L. (6\%) and Melastomatacae (3\%).

\section{Granulometry and Organic Carbon Content}

Results of granulometry and organic carbon content analysis are shown below. All samples were grouped in textural classes with a concentration of clay less than $35 \%$ and sand larger than $15 \%$ (Figure 5), an exception is the 


\section{Open Access Journal of Agricultural Research}

sample 2. Sample 2 is characterized by clayey texture since their concentration of clay varies from 35 to $60 \%$ [31]. Results (Table 1) and classification (Table 2) are shown below.

The data of organic carbon concentration were grouped in two classes according to quantitative classification for organic carbon and organic matter in the states of Rio Grande do Sul and Santa Catarina [30]. Samples 1, 2, 3, 4, 6 and 9 show average concentration of organic carbon from 1,5 to $3 \%$. Samples 5,7 and 8 is characterized by high concentration of organic carbon $(>3 \%)$. Table 1 and 2 presents the synthesized results.

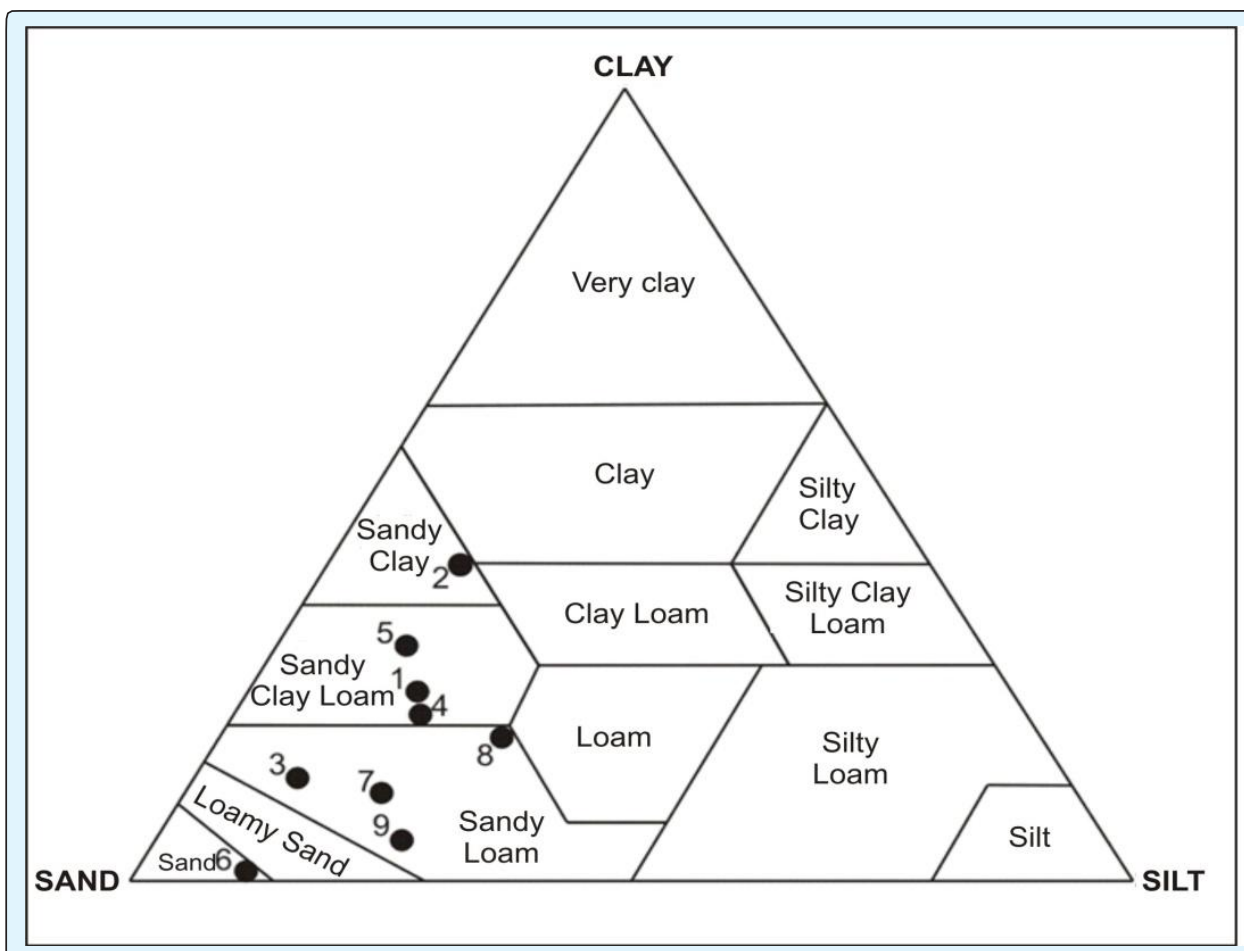

Figure 5: Ternary diagram textural classification of samples.

\begin{tabular}{|c|c|c|c|c|c|c|}
\hline Sample & $\begin{array}{c}\text { Pollen } \\
\text { concentration per } \\
\mathbf{c m}^{\mathbf{3}}\end{array}$ & $\begin{array}{c}\text { Organic } \\
\text { carbon (\%) }\end{array}$ & $\begin{array}{c}\text { Organic matter } \\
\mathbf{( \% )}\end{array}$ & Sand (\%) & Silt (\%) & Clay (\%) \\
\hline 1 & 36.613 & 1.96 & 3.37 & 58.38 & 17 & 24.62 \\
\hline 2 & 33.835 & 2.03 & 3.5 & 44.96 & 14.89 & 40.16 \\
\hline 3 & 29.901 & 1.49 & 2.56 & 75.84 & 11.06 & 13.1 \\
\hline 4 & 47.081 & 1.64 & 2.82 & 59.82 & 19.45 & 20.73 \\
\hline 5 & 108.6 & 11.3 & 19.43 & 56.51 & 13.45 & 30.04 \\
\hline 6 & 31.668 & 1.48 & 2.54 & 85.94 & 12.94 & 1.125 \\
\hline 7 & 53.92 & 3.41 & 5.86 & 68.28 & 20.17 & 11.55 \\
\hline 8 & 31.563 & 5.27 & 9.06 & 52.31 & 28.52 & 19.17 \\
\hline 9 & 25.562 & 2 & 3.44 & 69.57 & 25.22 & 5.217 \\
\hline
\end{tabular}

Table 1: Pollen concentration per $\mathrm{cm}^{3}$, results of the organic carbon, organic matter analysis and granulometry analysis of the samples. 


\section{Open Access Journal of Agricultural Research}

\begin{tabular}{|c|c|c|}
\hline Sample & Textural classification & $\begin{array}{c}\text { Organic carbon quantitative } \\
\text { classification }\end{array}$ \\
\hline 1 & Sandy Clay Loam & Medium concentration \\
\hline 2 & Sandy Clay & Medium concentration \\
\hline 3 & Sandy Loam & Medium concentration \\
\hline 4 & Sandy Clay Loam & Medium concentration \\
\hline 5 & Sandy Clay Loam & High concentration \\
\hline 6 & Sand & Medium concentration \\
\hline 7 & Sandy Loam & High concentration \\
\hline 8 & Sandy Loam & High concentration \\
\hline 9 & Sandy Loam & Medium concentration \\
\hline
\end{tabular}

Table 2: Pollen concentration per $\mathrm{cm}^{3}$, textural classification and organic carbon quantitative classification of the samples.

\section{Discussion}

Most of the palynological samples (89\%) reflected the modern vegetation of the studied region. Samples 1 and 9 collected in the grasslands were represented mainly by pollen grains of grasslands species. Sample 5 collected in the Araucaria forest showed pollen species of the same vegetation where the sample was collected. Samples 3, 4, 7 and 8 showed taxa of the two vegetation that represent the transition vegetation of local area collected. Only sample 2 not showed pollen spectrum similar to the vegetation area collected (grassland) and was characterized by pollen species of transitional vegetation. Although this sample had predominantly characteristic taxa of grassland, the significant presence of Myrtaceae trended the result, since in the study area most of the species of this family (Myrtaceae) occur in the boundary of the Araucaria forest.

The results of the physical-chemical analyzes that were submitted to the samples indicate materials predominantly of sandy texture, with organic carbon contents ranging from medium to high concentration. These data were included in the simple correlation test with data of correlation of pollen grains by $\mathrm{cm}^{3}$. The results indicate a perfect positive correlation between pollen grain concentration $\left(\mathrm{cm}^{3}\right)$ and clay contents $(0,99)$ and almost perfect positive correlation with the levels of organic carbon $(0,88)$. On the other hand, the correlation with sand is negative, however very low $(-0,23)$, as well as the correlation with the concentration of silt $(-0,27)$.

Even though the quantity of samples is relatively small, these results suggest that the concentration of pollen grains is associated with the clay and organic carbon concentration and not with the low concentration of sand as previously suggested [32].

\section{Conclusion}

Using 9 palynological samples through of comparison between modern pollen spectrum and vegetation, we found relationships in pollen-vegetation, well as well pollen-soil deposition and preservation. The palynological analysis of surface sediments is an important tool to analogous processes studies of Quaternary. The results obtained in this study showed that pollen spectrum reflects the modern vegetation and that is including sensitive to small changes and transition of vegetation.

Through this study is also possible to affirm that the high concentration of sand is not a limiting factor for the preservation of pollen grains. The results suggest that the concentration of pollen grains recorded in the sediment is associated with quantity of clay and organic carbon. In this way, the sediment may be predominantly sandy and still be suitable for studies in palynology.

\section{Acknowledgments}

We thank the CNPq (563307/2010-2) for the financial assistance for field travels. Our appreciation goes to Laboratório de Solos da ULBRA for infrastructure provided for particle size analysis and to colleagues Prof. MSc. Humberto do Amaral Duarte and Thales Castilhos de Freitas by laboratory assistance received for sample preparation. We thank Prof. Dr. Sérgio Augusto de Loreto Bordignon for the assistance in the botanical survey of the study region. 


\section{Open Access Journal of Agricultural Research}

\section{References}

1. Bauermann SG, Marques-Toigo M, Behling H, Neves PCP (2002) Aspectos tafonômicos em Palinologia de Quaternário. Pesquisas, Botânica 52: 223-239.

2. Mourelle D, Prieto AR (2012) Modern pollen assemblages of surface samples and their relationships to vegetation in the campos region of Uruguay. Review of Palaeobotany and Palynology 181: 22-33.

3. Soepboer W, Sugita S, Lotter AF, Leeuwen JFN, Van Knaap WO, et al. (2007) Pollen productivity estimates for quantitative reconstruction of vegetation cover on the Swiss Plateau. The Holocene 17(1): 65-77.

4. Campbell ID (1999) Quaternary pollen taphonomy: examples of differential redeposition and differential preservation. Palaeogeography, Palaeoclimatology, Palaeoecology 149(1-4): 245-256.

5. Hall SA (1981) Deteriorated pollen grains and the interpretation of quaternary pollen diagrams. Review of Palaeobotany and Palynology 32(2-3): 193-206.

6. Nielsen AB, Odgaard BV (2004) The use of historical analogues for interpreting fossil pollen records. Veget Hist Archaeobot 13(1): 33-43.

7. Lézine AM, Watrin J, Vincens A, Hély C (2009) Are modern pollen data representative of west African vegetation?. Review of Palaeobotany and Palynology 156(3-4): 265-276.

8. Barreto CF, Barth OM, Brenner W, Morgado LN, Vilela CG (2003) Análises palinológicas de sedimentos da superfície de depósitos do fundo da Baía de Guanabara, Rio de Janeiro, Brasil. In: IX Congresso da Associação Brasileira de Estudos do Quaternário, 1, Recife pp: 1-7.

9. São Thiago LEU, Barros MA, Barth OM (2007) Deposição palinológica atual em sedimentos de superfície do solo no médio vale do rio Paraíba do Sul (Estados de São Paulo e Rio de Janeiro). Anu Inst Geocienc 30(2): 55-64.

10. Evaldt ACP (2013) Reconstituição Paleoambiental em remanescente de Savana Estépica Parque no extremo oeste do Rio Grande do Sul (Barra do Quaraí), com base em palinomorfos holocênicos. Universidade Federal do Rio Grande do Sul, Dissertação de Mestrado pp: 139.
11. Brasil (1973) Descrição geral do estado do Rio Grande do Sul. In Levantamento de Reconhecimento dos Solos do Estado do Rio Grande do Sul-Boletim Técnico no 30 . Ministério da Agricultura, Departamento Nacional de Pesquisa Agropecuária, Divisão de Pesquisa Pedológica.

12. Moreno JA (1961) Clima do Rio Grande do Sul. In: Secção de Geografia. Secretaria da Agricultura. Porto Alegre.

13. Rambo B (1956) A Fisionomia do Rio Grande do Sul. Selbach pp: 95.

14. Cordeiro JLP, Hasenack H (2009) Cobertura Vegetal Atual do Rio Grande do Sul. In: Pillar VD et al. Campos Sulinos: conservação e uso sustentável da biodiversidade. Pp: 296.

15. Reitz R, Klein RM, Reis A (1983) Projeto madeira do Rio Grande do Sul. Sellowia 34-35: 1-525.

16. Abraão NS (1992) História do Município de Caçapava do Sul - lendas, folclore e turismo. Porto Alegre.

17. Nascimento JK (2009) Palinoflora de Caçapava do Sul, Rio Grande do Sul, Brasil. Curso de Ciências Biológicas, Universidade Luterana do Brasil. Trabalho de Conclusão de Curso, Canoas pp: 32.

18. Faegri K, Iversen L (1989) Textbook of pollen analysis. 4th ed., New York, Hafner Publisher, pp: 486.

19. Stockmarr J (1971) Tablets with spores used in absolute pollen analysis. Pollen and Spores 13: 615621.

20. Heusser CJ, Moar NT (1973) Pollen and Spores of Chile: Modern Types of the Pteridophyta, Gymnospermae and Angiospermae. New Zealand Journal of Botany pp: 167.

21. Melhem TS, Cruz-Barros MAV, Corrêa AM, MakinoWatanabe H, Silvestre-Capelato MSF, et al. (2003) Variabilidade polínica em plantas de campos de Jordão (São Paulo, Brasil). Instituto de Botânica pp: 104.

22. Evaldt ACP, Bauermann SG, Fuchs SCB, Diesel S, Cancelli RR (2009) Grãos de pólen esporos do Vale do Rio Caí, nordeste do Rio Grande do Sul, Brasil: descrições morfológicas e implicações paleoecológicas. Gaea 5(2): 86-106. 


\section{Open Access Journal of Agricultural Research}

23. Bauermann SG, Evaldt ACP, Zanchin JR, Bordignon SAL (2010) Diferenciação polínica de Butia, Euterpe, Geonoma, Syagrus e Thritrinax e implicações paleoecológicas de Arecaceae para o Rio Grande do Sul. Iheringia Sér Bot 65(1): 35-46.

24. Cancelli RR, Evaldt ACP, Bauermann SG, Souza PA, Bodignon SAL, et al. (2010) Catálogo polinológico de táxons da família Asteraceae Martinov, no Rio Grande do Sul, Brasil. Iheringia Sér Bot 65(2): 201-280.

25. Evaldt ACP, Bauermann SG, Cancelli RR, Acioli M, Neves PCP (2011) Morfologia polínica de Passifloraceae Juss. ex Kunth. no Rio Grande do Sul, Brasil. Revista Brasileira de Biociências 9(1): 75-87.

26. Behling H, Verissimo N, Bauermann S, Bordignon S, Evaldt A (2016) Late Holocene Vegetation History and Early Evidence of Araucaria angustifolia in Caçapava do Sul in the Lowland Region of Rio Grande do Sul State, Southern Brazil. Brazilian Archives of Biology and Technology 59: e16150264.
27. Rede de catálogos polínicos online. Available: < http://chaves.rcpol.org.br/ >.

28. Bennett K (2003) PSimpoll software. Available: http://www.kv.geo.uu.se/psimpoll.html

29. Suguio K (1973) Introdução à sedimentologia. São Paulo, Edgard Blucher pp: 317.

30. Tomé Jr JB (1997) Manual para interpretação de análise de solo. Guaíba Agropecuária pp: 247.

31. IBGE (2007) Manual Técnico de Pedologia. Coordenação de Recursos Naturais e Estudos Ambientais. Rio de Janeiro, Manuais Técnicos em Geociências 4.

32. Salgado-Labouriau ML (2007) Critérios e técnicas para o Quartenário (1edn) São Paulo: Edgard Blücher. 